\title{
Florida Bromeliad Weevil (no official common name), Metamasius mosieri Barber (Insecta: Coleoptera: Curculionidae: Dryophthorinae) ${ }^{1}$
}

\section{Barbara Larson, J. Howard Frank, and Olan Ray Creel $^{2}$ \\ Introduction and Distribution}

Metamasius mosieri Barber is native to Cuba and the Dominican Republic and likely to southern Florida. Until recently, it was rarely collected in Florida (most likely because until recently no specific effort was made to find it). It has been reported from Collier (Corkscrew Swamp, Rookery Bay, Collier-Seminole State Park, Fakahatchee Strand), Glades (Fisheating Creek), Hendry (LaBelle, Big Cypress Seminole Reservation) Sarasota (Laurel), Lee, Dade, St. Lucie and Osceola Counties. The Florida bromeliad weevil is an occasional and minor pest on ornamental bromeliads and occurs at very low population densities in its natural habitat. It should not be confused with the Mexican bromeliad weevil, Metamasius callizona, which is currently attacking five species of native bromeliads in 16 counties and will likely destroy populations of six additional species of already-threatened or endangered bromeliads if not brought under control.

\section{Description}

The Florida bromeliad weevil is considerably smaller than the other two species of Metamasius weevils currently found in Florida. The adult is 6 to $11 \mathrm{~mm}$ in length, with males usually slightly smaller than females. Adults are red and black, with most of the thorax and upper half of the elytra being red, and they have two black spots about midway on the elytra. There is some variation in the size and shape of these spots, and occasionally two additional, smaller black spots are present above them. In Osceola County, a darker color form has been observed, which is nearly all black except for a thin, red line on the thorax dorsally and red coloration on the head.

The Florida bromeliad weevil can easily be distinguished in the adult stage from the Mexican bromeliad weevil, Metamasius callizona, and the silky cane weevil, Metamasius hemipterus (L.), by both size and coloration. Larvae of the three species are similar in appearance, except that mature larvae of $M$. mosieri are smaller than those of the other two species.

1. This document is EENY-209, one of a series of Featured Creatures from the Entomology and Nematology Department, Florida Cooperative Extension Service, Institute of Food and Agricultural Sciences, University of Florida. Published: May 2001. This document is also available on Featured Creatures Website at http://creatures.ifas.ufl.edu. Please visit the EDIS Website at http://edis.ifas.ufl.edu.

2. Barbara Larson, J. Howard Frank, Entomology and Nematology Department, University of Florida, and Olan Ray Creel.

The Institute of Food and Agricultural Sciences is an equal opportunity/affirmative action employer authorized to provide research, educational information and other services only to individuals and institutions that function without regard to race, color, sex, age, handicap, or national origin. For information on obtaining other extension publications, contact your county Cooperative Extension Service office. Florida Cooperative Extension Service/Institute of Food and Agricultural Sciences/University of Florida/Christine Taylor Waddill, Dean. 


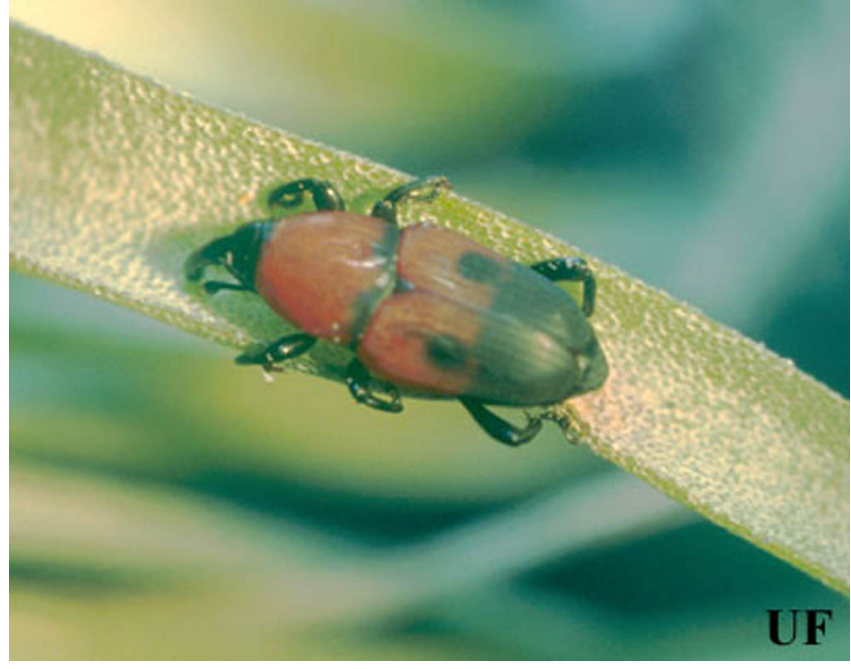

Figure 1. Adult Metamasius mosieri Barber, the Florida bromeliad weevil. Credits: B. Larson, University of Florida

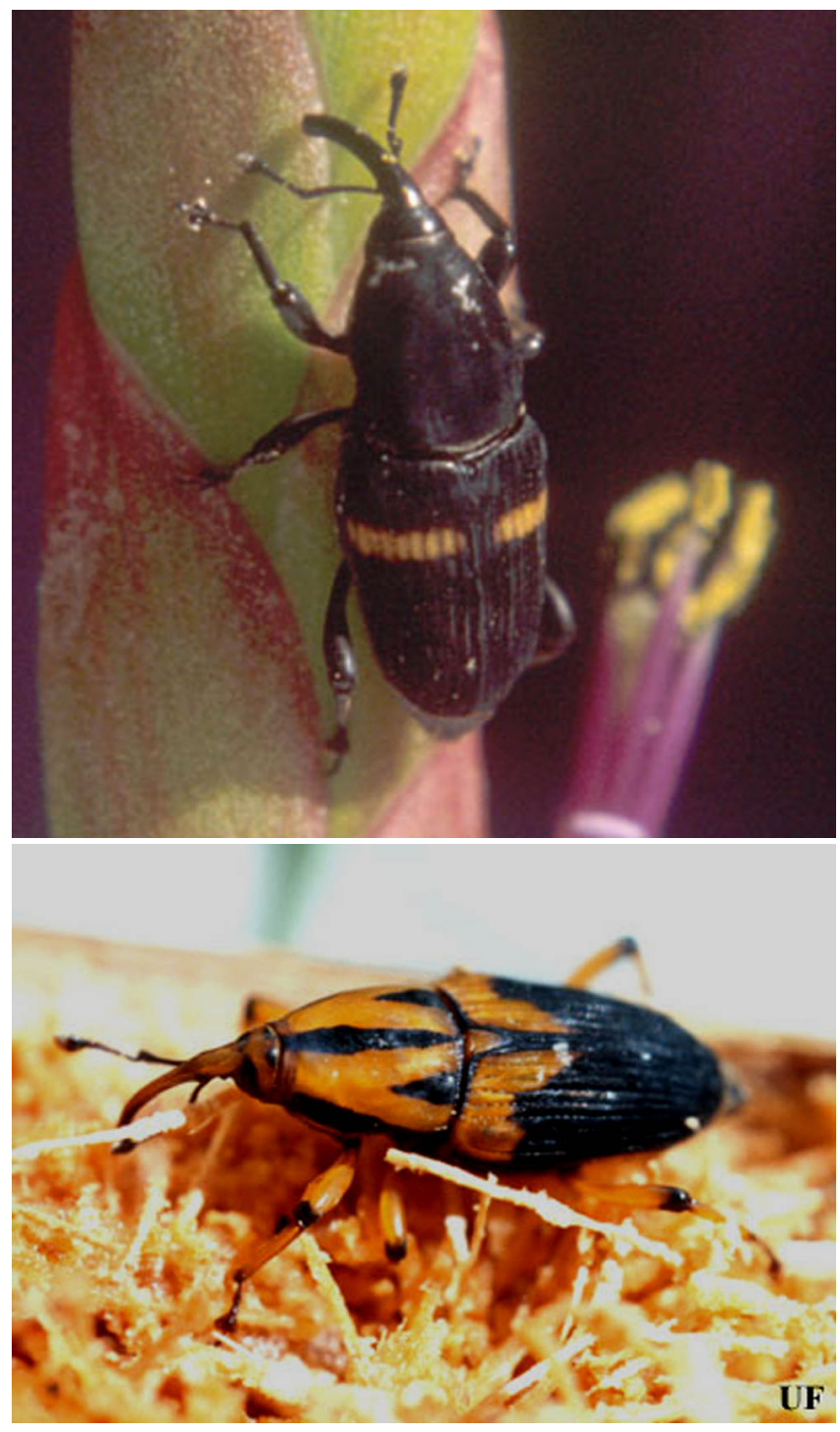

Figure 3. Adult Metamasius hemipterus (L.), the silky cane weevil. Credits: B. Larson, University of Florida

\section{Host Plants}

In Florida, the weevil has been found most commonly on Tillandsia balbisiana, T. utriculata, $T$. variabilis, and T. setacea, although it also occurs on several additional species of native bromeliads (Family Bromeliaceae), including T. fasciculata, $T$. simulata, T. paucifolia, T. flexuosa, T. bartramii and the natural hybrid T. $x$ smalliana. When it occurs on larger species such as T. utriculata and T. fasciculata, it appears limited to seedlings and immature individuals of those plants (generally up to about 16 $\mathrm{cm}$ from leaf base to tip). It has also been observed in grower shadehouses to attack some small species of Tillandsia exotic to Florida, including T. bergeri, $T$. bulbosa, T. concolor, T. geminiflora, T. gardneri, $T$. hondurensis, T. ionantha, T. jucunda, T. rhomboidae, T. streptophylla, T. stricta and T. vernicosa.

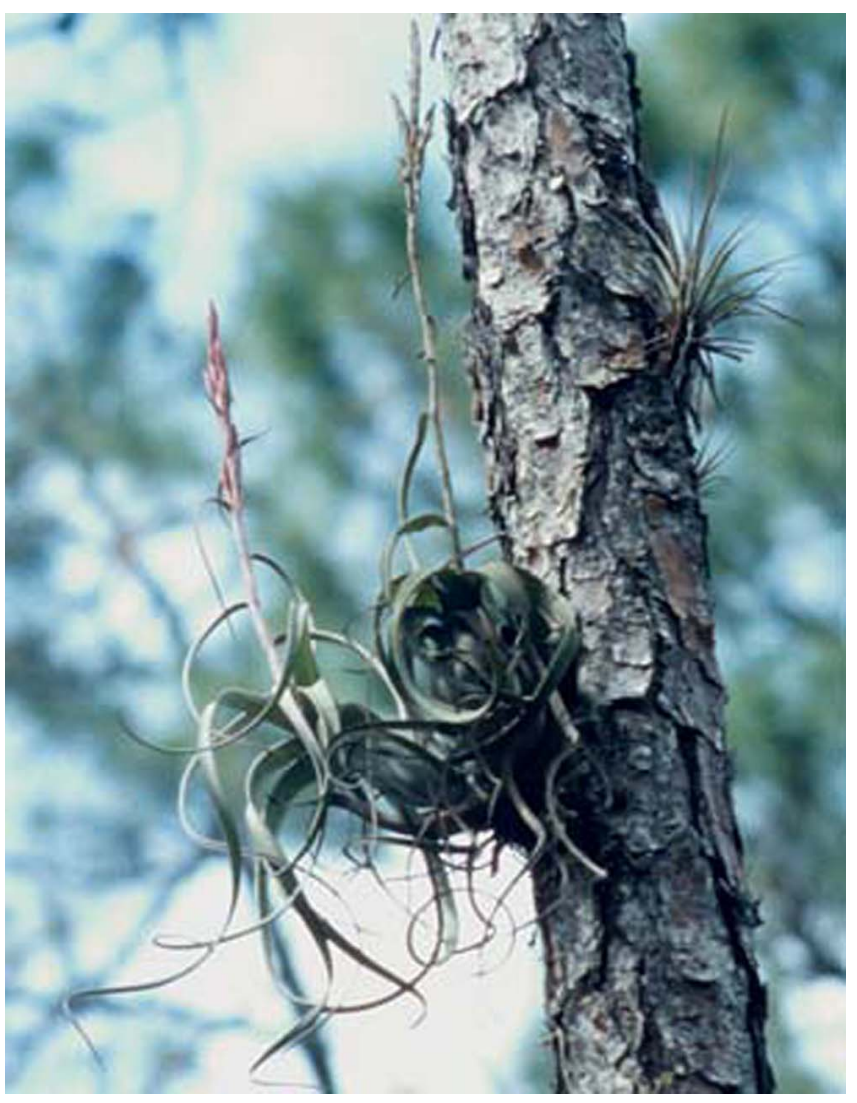

Figure 4. Tillandsia balbisiana Schultes, one of the principal host plants of the Florida bromeliad weevil, Metamasius mosieri Barber. Credits: B. Larson, University of Florida

For more information, see Florida Native Bromeliads Illustrated WWW site at: http://bromeliadbiota.ifas.ufl.edu/flbrom.htm. 


\section{Biology and Damage}

Development time appears to be somewhat longer than that of the Mexican bromeliad weevil. Observed development time under ambient conditions in St. Lucie County from egg to adult has ranged from 18 to 22 weeks. All stages of M. mosieri maintained in St. Lucie County have been observed to survive four- to six-hour periods of freezing temperatures $\left(-1.1^{\circ} \mathrm{C}\right.$ or $\left.30^{\circ} \mathrm{F}\right)$, as well as temperatures up to $35.5^{\circ} \mathrm{C}\left(96^{\circ} \mathrm{F}\right)$. The weevil remains active at temperatures between about $12.8^{\circ}$ $\mathrm{C}\left(55^{\circ} \mathrm{F}\right)$ and $32.2^{\circ} \mathrm{C}\left(90^{\circ} \mathrm{F}\right)$.

Adults feed externally on leaves, and they may also feed on flowerstalks and inflorescences as do adults of other weevils that are specialists on bromeliads. Females of the Florida bromeliad weevil deposit eggs singly. The eggs, which are approximately $3 \mathrm{~mm}$ in length, have been found both on the surface of leaves in the center of the plant and within slits in the leaf made by the female. Females generally lay one egg per plant, and when more are laid on a single plant, cannibalism in the larval stage usually reduces the number of individuals to one per plant. Adults are known to survive at least eight months under ambient conditions in St. Lucie County, and females have been observed to continue laying eggs for at least seven months.

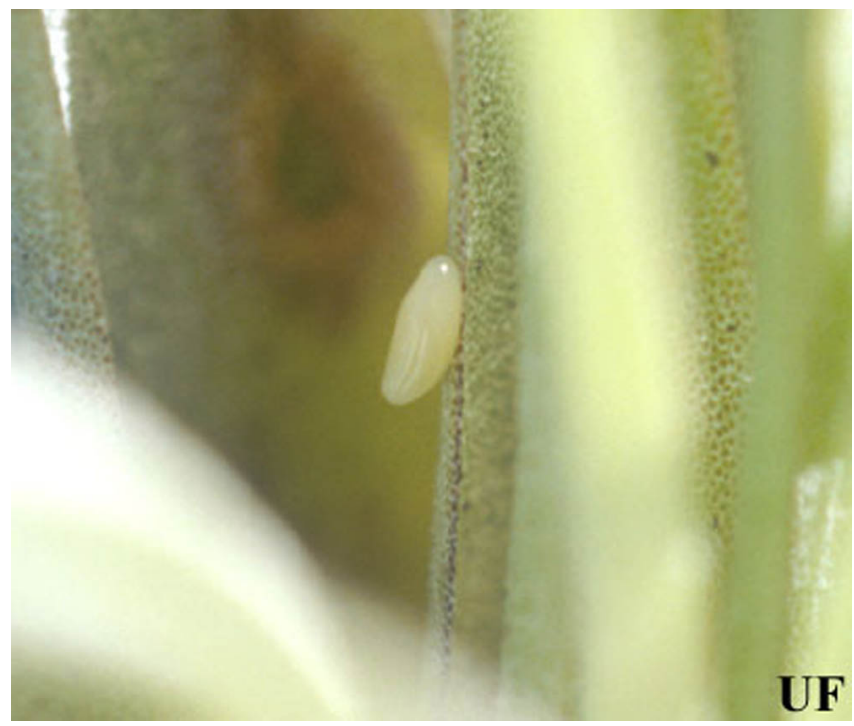

Figure 5. Egg of Metamasius mosieri Barber, the Florida bromeliad weevil. Credits: B. Larson, University of Florida

Upon hatching, larvae eat through the outer layer of leaf tissue. Larger larvae, which grow to approximately $11 \mathrm{~mm}$ in length, chew through leaves in the center of the plant, less frequently tunneling into the base of the plant as do larvae of the Mexican bromeliad weevil. Larvae have also been observed mining the flowerstalks of mature plants, without killing them.

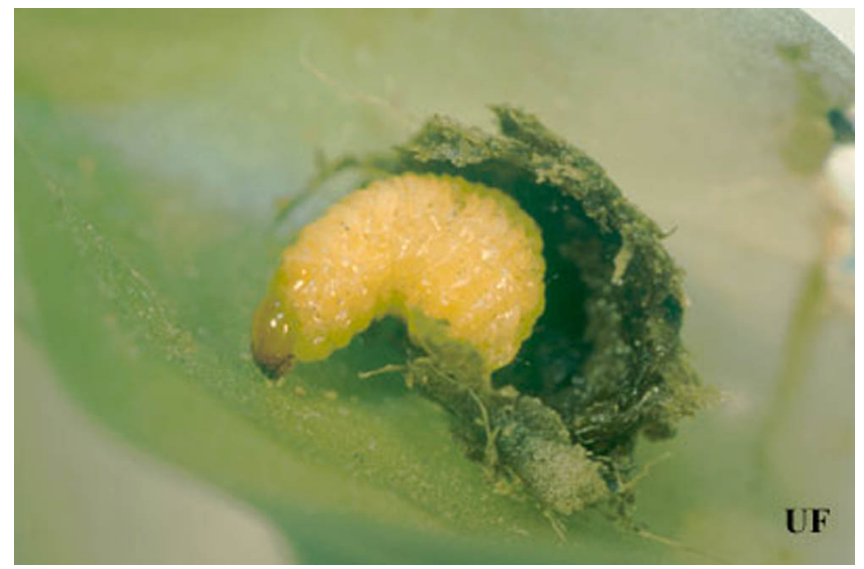

Figure 6. Larva of Metamasius mosieri Barber, the Florida bromeliad weevil. Credits: B. Larson, University of Florida

As larvae feed in the center of the plant, they push shredded leaf material up, forming a plug between the leaves, which probably serves as protection against desiccation or natural enemies. Pupation occurs within the plant, often just below the plug, inside a cocoon constructed by the larva from shredded leaf tissue. Approximate time in the pupal stage under ambient conditions in St. Lucie County has been observed to be two to three weeks.

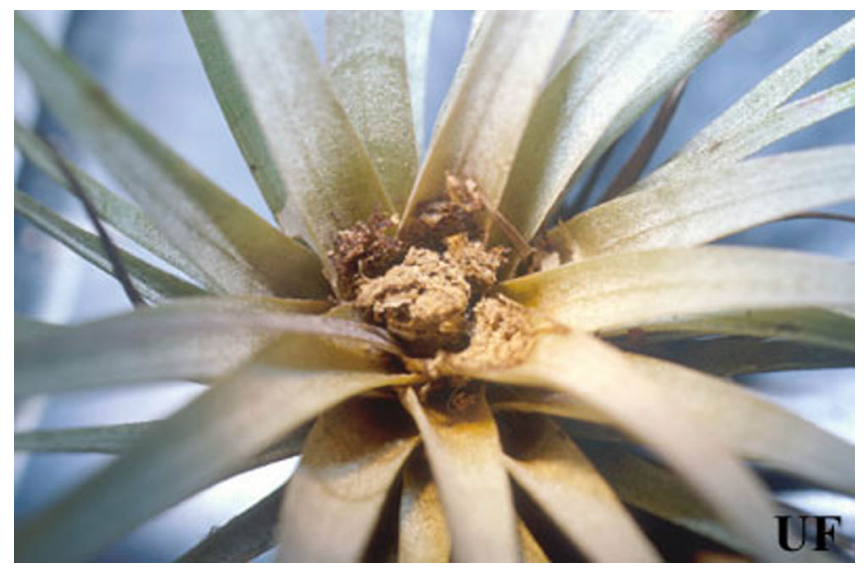

Figure 7. Plug over damage on Tillandsia utriculata (L.) constructed by larva of Metamasius mosieri Barber, the Florida bromeliad weevil. Credits: B. Larson, University of Florida

While damage to individual plants from Metamasius mosieri is considerably less than that 


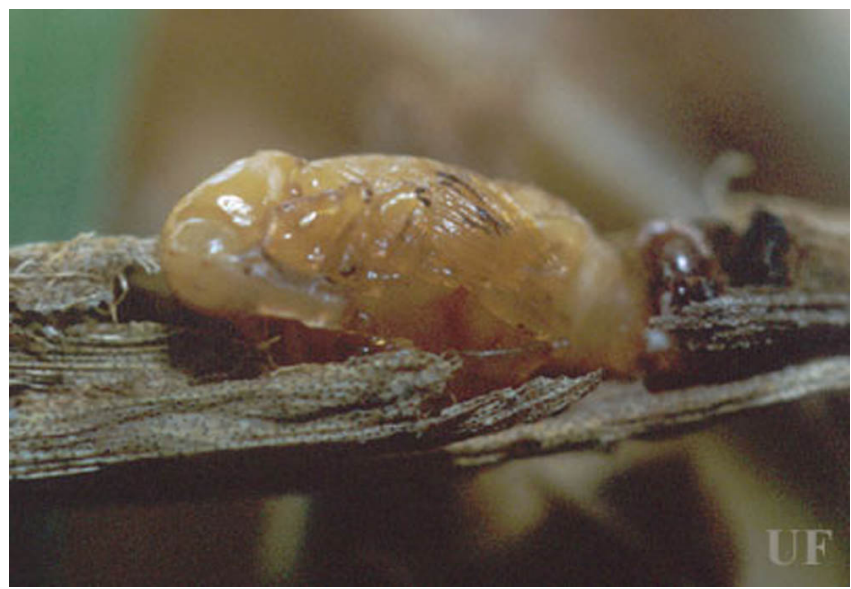

Figure 8. Pupa of Metamasius mosieri Barber, the Florida bromeliad weevil. Credits: B. Larson, University of Florida

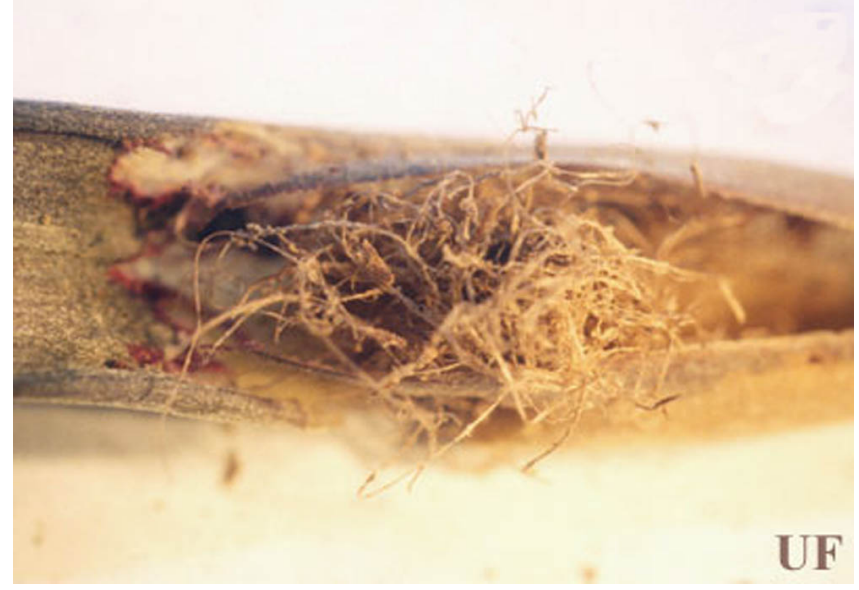

Figure 9. Leaf tissue shredded in preparation for cocoon construction by Metamasius mosieri Barber, the Florida bromeliad weevil. Credits: B. Larson, University of Florida

from Metamasius callizona, the Florida bromeliad weevil has been reported killing plants of several native bromeliads in Florida. However, its effects on bromeliad populations are generally insignificant, because the Florida bromeliad weevil is found in low population densities and largely attacks seedlings and immature plants. Greatest damage in natural areas has been observed in St. Lucie County in bromeliad populations already affected by the Mexican bromeliad weevil, M. callizona. The effects of $M$. callizona presence on population dynamics of $M$. mosieri are still unclear. In addition to the plug that can be seen in the center of most infested plants, chewing on the base of central leaves serves as a sign of the presence of the Florida bromeliad weevil.

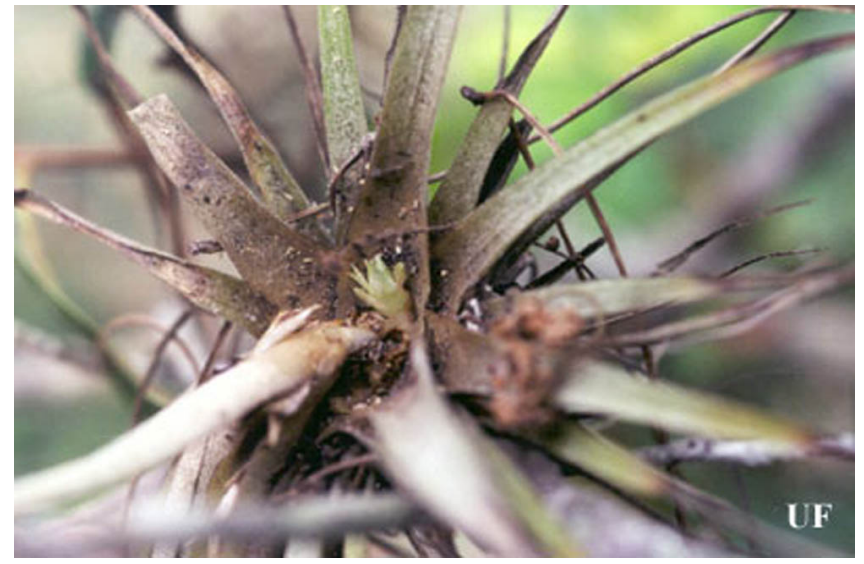

Figure 10. Damage to Tillandsia utriculata (L.) from Metamasius mosieri Barber, the Florida bromeliad weevil. Credits: B. Larson, University of Florida

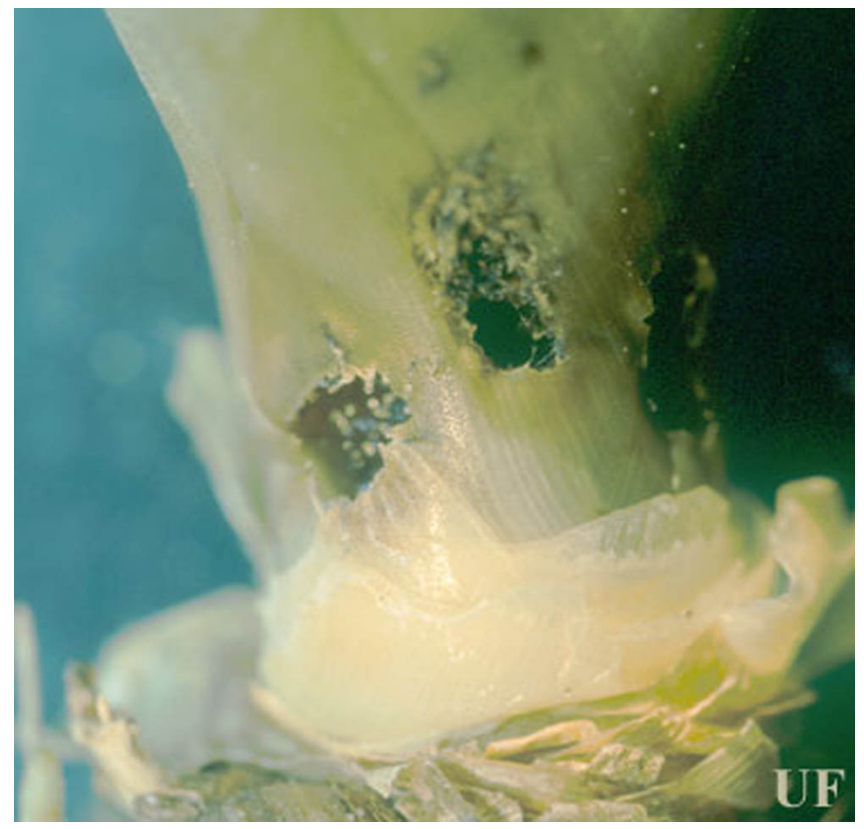

Figure 11. Holes at base of stem of Tillandsia utriculata (L.) from Metamasius mosieri Barber, the Florida bromeliad weevil. Credits: B. Larson, University of Florida

\section{Management}

In natural areas, the Florida bromeliad weevil does not damage host plant populations enough to warrant management efforts. In bromeliad nurseries or private collections, it is a very infrequent and minor pest. If necessary, it can be controlled with a reduced concentration of an insecticide labeled for beetle adults and grubs, applied as a spray or dip every two to three months to prevent infestations. This recommendation is based on general principles and not on specific efficacy data, since no chemical 


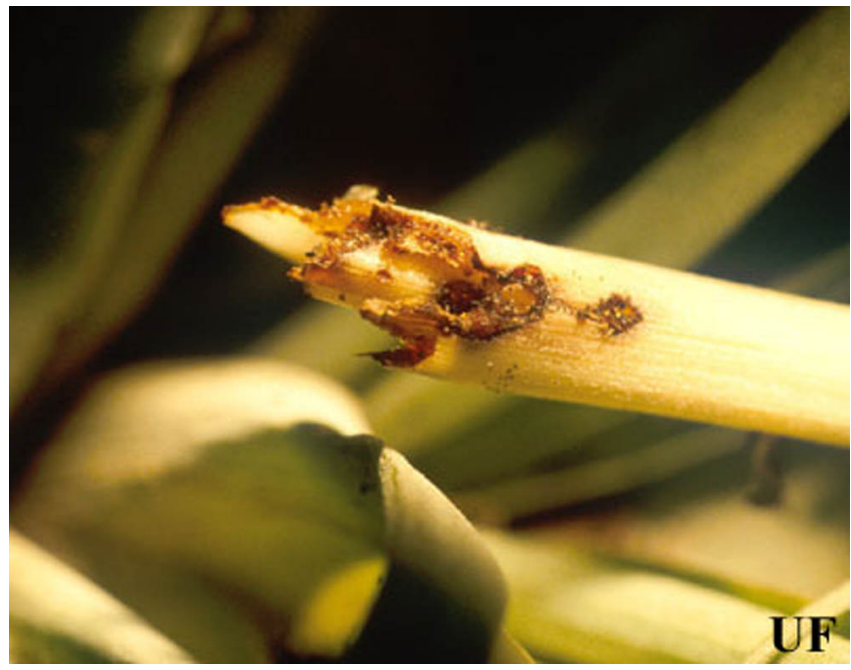

Figure 12. Damage to base of leaves of Tillandsia utriculata (L.) from Metamasius mosieri Barber, the Florida bromeliad weevil. Credits: B. Larson, University of Florida

trials of any pesticide have been carried out against the weevil.

Insect Management Guide for Ornamentals [see Beetles]

Landscape Plant Insect Management Suggestions

\section{Selected References}

Barber, H.S. 1920. A new tropical weevil from Florida and Cuba. Proc. Ent. Soc. Washington 22:150-152.

Creel, O.R. 2000. Up-close and personal with the evil weevil: One man's encounters with Metamasius callizona. http://www.fcbs.org/articles/olan_creel.htm (2 April 2001).

Frank, J.H. 1999. Bromeliad-eating weevils. Selbyana 20:40-48.

Frank, J.H. and M.C. Thomas. (September 2000). Weevils that eat bromeliads. http://bromeliadbiota.ifas.ufl.edu/wvbrom.htm (2 April 2001).

O'Brien, C.W. and M.C. Thomas. 1990. The species of Metamasius in Florida (Coleoptera: Curculionidae). Fla. Dept. of Agric. \& Consumer Services, Division of Plant Industry, Entomology Circular No. 330.
Vaurie, P. 1966. A revision of the Neotropical genus Metamasius (Coleoptera, Curculionidae, Rhynchophorinae). Species groups I and II. Bull. American Mus. Natur. Hist. 131:213-337. 